\title{
Evaluation of surficial sediment toxicity and sediment physico-chemical characteristics of representative sites in the Lagoon of Venice (Italy)
}

\author{
C. Losso ${ }^{a}$, A. Arizzi Novelli ${ }^{a}$, M. Picone ${ }^{a}$, D. Marchetto ${ }^{a}$, G. Pessa ${ }^{a}$, \\ E. Molinaroli ${ }^{\text {b }}$, P.F. Ghetti ${ }^{\text {b }}$, A. Volpi Ghirardini ${ }^{\text {a,* }}$ \\ ${ }^{a}$ Department of Environmental Sciences, University of Venice, Campo della Celestia 2737/b, I-30122 Venice, Italy \\ ${ }^{\mathrm{b}}$ Department of Environmental Sciences, University of Venice, Calle larga S. Marta 2137, I-30123 Venice, Italy
}

Received 20 December 2002; accepted 19 May 2004

Available online 17 July 2004

\begin{abstract}
Toxic hazard in sites with varying types and levels of contamination in the Lagoon of Venice was estimated by means of toxicity bioassays based on the early life-stages of the autochthonous sea urchin Paracentrotus lividus. Elutriate was chosen as the test matrix, due to its ability to highlight potential toxic effects towards sensitive biological components of the water column caused by sediment resuspension phenomena affecting the Lagoon. Surficial sediments (core-top $5 \mathrm{~cm}$ deep), directly influenced by resuspension/redeposition processes, and core sediments (core $20 \mathrm{~cm}$ deep), recording time-mediated contamination, were sampled in some sites located in the lagoonal area most greatly influenced by anthropogenic activities. Particle size, organic matter and water content were also analysed. In two sites, the results of physical parameters showed that the core-top sediments were coarser than the 20 -cm core sediments. Sperm cell toxicity test results showed the negligible acute toxicity of elutriates from all investigated sites. The embryo toxicity test demonstrated a short-term chronic toxicity gradient for elutriates from the $20-\mathrm{cm}$ core sediments, in general agreement both with the expected contamination gradient and with results of the Microtox ${ }^{\circledR}$ solid-phase test. Elutriates of the core-top 5-cm sediments revealed a totally inverted gradient, in comparison with that for the $20-\mathrm{cm}$ core sediments, and the presence of a "hot spot" of contamination in the site chosen as a possible reference. Investigations on ammonia and sulphides as possible confounding factors excluded their contribution to this "hot spot". Integrated physico-chemical and toxicity results on sediments at various depths demonstrated the presence of disturbed sediments in the central basin of the Lagoon of Venice.
\end{abstract}

(C) 2004 Elsevier B.V. All rights reserved.

Keywords: Sea urchin; Paracentrotus lividus; Sperm cell toxicity test; Embryo toxicity test; Elutriate; Sediment grain size; Sediment resuspension

* Corresponding author.

E-mail address: voghi@unive.it (A. Volpi Ghirardini).

\section{Introduction}

The lagoon of Venice is a complex system characterized by high macro- and microvariability and by dynamics greatly influenced by anthropo- 
genic activities (Ravera, 2000). A recent monitoring program (Venice Water Authority, 1999) has been carried out to assess the distribution of priority micropollutants in surface sediments, highlighting the presence of heavy metals, hydrocarbons, PAHs, PCBs and PCDD/Fs. A pollution gradient from the Industrial Zone towards the sea inlets was evidenced and pollutant loadings estimated (Critto and Marcomini, 2001). Recent studies have demonstrated that, in the last few decades, several modifications have occurred in hydrodynamics (Melaku Canu et al., 2001) and throphic conditions (Sfriso and Marcomini, 1996; Sfriso et al., 2003). High levels of suspended particulate matter were evidenced by remote sensing (Rosselli et al., 2002), particularly in the most highly anthropized central basin of the Lagoon, where other studies have demonstrated that sediment fluxes into the water column have increased by about 4- to 11fold on a yearly basis (Facca et al., 2002; Sfriso et al., 2003). Moreover, since the early 1980s, the introduction and rapid diffusion in the Lagoon of the allochthonous bivalve Tapes philippinarum (Adams and Reeve, 1950) has determined a sharp increase in the number of bivalve fisheries and also illegal fishing (Facca et al., 2002). Exploitation of this resource by means of high impact gears (Pranovi and Giovanardi, 1994) causes increased sediment resuspension. Large quantities of resuspended particulate matter and associated pollutants may have, as direct consequences, redistribution of contaminants and biological effects on the benthic community and water column organisms (Orel et al., 2000; Volpi Ghirardini et al., 2003).

Estimating toxic hazard due to sediment contamination by means of toxicity bioassays is valuable, because only "biological instruments" are able to integrate the various complex effects of pollutant mixtures. In the present work, toxicity bioassays based on the early life-stages of the autochthonous sea urchin Paracentrotus lividus (Lamark, 1816) (sperm cell toxicity and embryo toxicity tests) were used to assay elutriates, to assess potential toxic effects due to sediment resuspension.

Sea urchin toxicity bioassays are internationally recognized as reliable, sensitive and ecologically important tools for biomonitoring marine and estuarine environments (ICES, 1997; US EPA, 2000) and standard methods are available in some countries (Environment Canada, 1992; US EPA, 1994, 1995; ASTM, 1995). Toxicity bioassays using gametes and embryos of P. lividus are being studied in some Italian research laboratories by means of several methodologies (Arizzi Novelli et al., 2001). Two tests have been developed for P. lividus with reference to standard procedures, a sperm cell toxicity test (Volpi Ghirardini and Arizzi Novelli, 2001) and an embryo toxicity test (Arizzi Novelli et al., 2002a), both of which have been demonstrated to be reliable, effective predictive and protective biological tools. In addition, on the basis of data available for pure compounds compared with results obtained on other acute and chronic tests, the sperm cell toxicity test may be considered as acute and the embryo toxicity test as short-term chronic. The sensitivity and discriminatory ability of both tests were evaluated using elutriates from sediments in the Lagoon of Venice as test matrices (Arizzi Novelli et al., 2002b; Volpi Ghirardini et al., 2004 , in press). Sea urchin toxicity tests have been recommended for toxicity assessment of elutriates (Environment Canada, 1992; ICES, 1997; Nendza, 2002), and P. lividus male gametes and embryos have been used in previous studies to assess the toxicity of elutriates from sediments both of the historical city centre of Venice (Da Ros et al., 1997; McFadzen, 2000) and of other sites (industrial, estuarine and shallow waters) in the Lagoon (Volpi Ghirardini et al., 1999, 2003).

In order to evaluate toxicity by taking into account anthropogenic sediment alteration, two different types of sediment samples were collected: (i) a surficial sediment $(5 \mathrm{~cm}$ deep), directly influenced by resuspension/redeposition processes, and (ii) a deeper sediment (20 cm deep), recording timeintegrated contamination. As contaminant concentrations often correlate with the finest fractions of sediments, physical parameters (grain size, organic matter, water content) were also analyzed. High gradients of sediment contamination in the Lagoon of Venice from the Industrial Zone to the sea inlets (Venice Water Authority, 1999) indicated the most suitable areas for sediment collection. Elutriate was chosen as the matrix for toxicity tests because it is representative of water-extractable components. It is recommended in cases of sediment dredging, resus- 
pension and movement in aquatic environments (US EPA and US ACE, 1998) for its ability to give information on potential effects towards sensitive biological components of the water column, including gametes, embryos and larvae.

In recent years, the occurrence in test matrices (elutriates and particularly porewater) of "confounding factors" (such as ammonia, sulphides) has given rise to frequent "false positives" which may lead to inaccurate conclusions (Lapota et al., 2000). At present, indications for acceptable ranges of ammonia and sulphides in these matrices are not available in the literature (Lapota et al., 2000) and sediment toxicity identification evaluation (TIE) studies have been proposed (Wang and Chapman, 1999). For these reasons, we chose to proceed with caution, investigating potential contributions to the toxicity of ammonia and sulphides, identifying their concentrations in environmental samples, and comparing them with the sensitivity data available for sea urchin methods.

\section{Materials and methods}

\subsection{Sediment sampling}

Four sampling sites (Fig. 1) covering varying types and levels of contamination were selected in coordination with other research groups (Co.Ri.La. Project, Line 3.3. "Efficiency of the lagoon metabolism") and based on previous data. Three sites (SE, CEL, TR) were located in zones influenced by anthropogenic activities, in shallows characterized by bare substrates. A fourth sampling site (DE) was located in an estuarine area.

One station (SE) was close to the island of Sant'Erasmo, in an area characterized by fast water turnover (Melaku Canu et al., 2001), due to the proximity of the Lido sea inlet, and presumably also by a minimum degree of contamination. This site had in fact already been investigated during a recent study on contamination of core sediment samples $(15 \mathrm{~cm}$ deep) and was classified as a high-quality site (class A

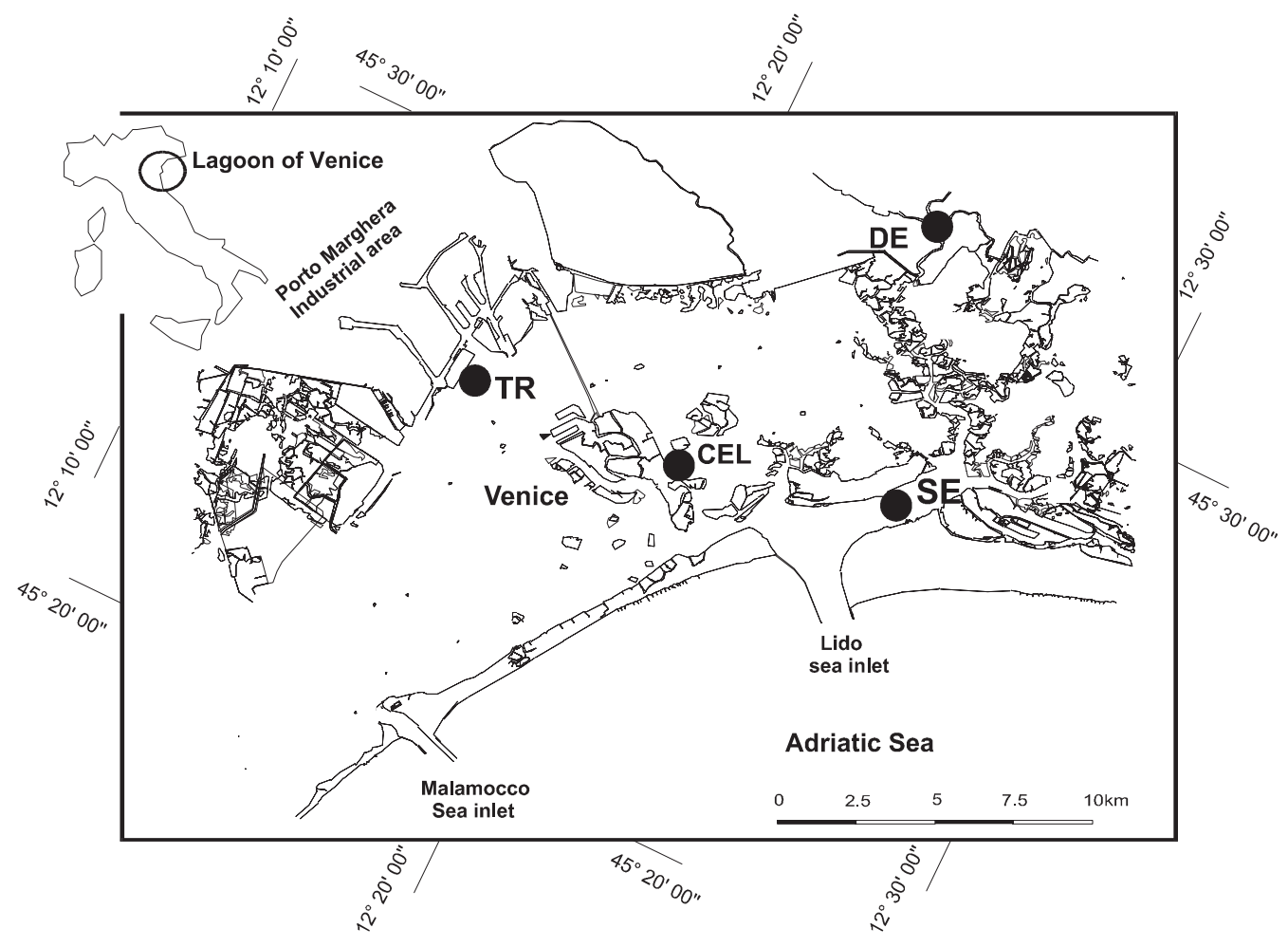

Fig. 1. Study area and sampling sites in the lagoon of Venice, Italy. $\mathrm{DE}=$ Dese River estuary, $\mathrm{TR}=\mathrm{Tresse}, \mathrm{CEL}=\mathrm{Celestia}, \mathrm{SE}=\mathrm{S}$. Erasmo. 
for both organic and inorganic micropollutants) (Venice Water Authority, 1999; Volpi Ghirardini et al., 2003) according to current quality criteria used to classify dredged sediments in the Lagoon of Venice (Volpi Ghirardini et al., 2001). For this reason, this site was chosen as a possible reference. The second site, Celestia (CEL), was located between the island of Murano and the northeastern side of the city of Venice. The site receives untreated municipal wastewater (from Venice city centre) and may also be affected by contamination from industrial sources, due to the vicinity of Murano, where several glass factories are located. The contamination level of the area near the site is medium for heavy metals (class B) and higher for organic micropollutants (class C) (Volpi Ghirardini et al., 2003). The third station (TR) was located off Tresse, an artificial island composed of rubble dredged from the Industrial Zone channels near Porto Marghera. This site had already been investigated from a chemical point of view, and had revealed high contamination levels of both heavy metals and organic micropollutants (class C) (Volpi Ghirardini et al., 2003).

The fourth station (DE), located in the estuary of the river Dese, is affected by pollution from agricultural drainage. It had been studied by our research group and showed a medium contamination level (class B) for both organic and inorganic micropollutants and moderate toxicity (Volpi Ghirardini et al., 2003).

Core sediment samples were collected in November 2001. At each site, the area (a circle approximately $30 \mathrm{~m}$ across, with a central point fixed by geographical co-ordinates), and sample dimensions (8 and 16 sediment cores for depths of 20 and 5 $\mathrm{cm}$, respectively) were defined, and integrated sampling (with cores equally distributed in the area) was carried out in order to take into account any spatial microvariability in pollution/bioavailability, according to the scheme reported in Volpi Ghirardini et al. (2004, in press). Samples were collected using an 8-cm-diameter Plexiglas corer. In the text, the numbers 5 and 20 after the site identification labels indicate the core-top 5-cm sediment samples and the core $20-\mathrm{cm}$ sediments samples, respectively. Samples were placed in 2-1 glass jars, filled without leaving any headspace, and then sealed hermetically to prevent oxidation. The jars were kept refrigerated until transport to the laboratory, where samples were stored at $4{ }^{\circ} \mathrm{C}$ until homogenization in nitrogen atmosphere using a Teflon ${ }^{\circledR}$-coated scoop. Homogenization was carried out within $24 \mathrm{~h}$ of sediment collection. Several subsamples were prepared for sediment characterization and processing, to obtain elutriates for toxicity bioassays and chemical analyses.

\subsection{Sediment characterization}

Each homogenized sediment sample was prepared for analyses of grain size, volatile organic matter and water content.

Sediment cores were thoroughly washed with distilled water to remove residual sea salts. The sediments were treated with $\mathrm{H}_{2} \mathrm{O}_{2}$ to remove organic matter and then oven-dried at $45{ }^{\circ} \mathrm{C}$. The dry samples were sieved through a $62-\mu \mathrm{m}$ sieve in order to separate sand from the pelitic fraction $(<62 \mu \mathrm{m})$. The sample fraction $<62 \mu \mathrm{m}$ was dispersed in a $6 \% 0$ Na-hexametaphosphate solution for $24 \mathrm{~h}$ and ultrasonically treated (bath) for a time not exceeding 10 min. The grain size distribution in $<62 \mu \mathrm{m}$ fraction was determined by Micromeritics SediGraph 5000D (Mönchengladbach, Germany).

The percentage of water content was calculated as the weight difference between wet and dried sediments (dried overnight at $105{ }^{\circ} \mathrm{C}$ ) (ASTM, 1990), in three replicates for each sediment sample. Volatile organic matter content was determined by subtracting the weight of a sediment aliquot burned at $450{ }^{\circ} \mathrm{C}$ from the weight of the same aliquot dried at $105{ }^{\circ} \mathrm{C}$ (loss-on-ignition), in three replicates for each sediment sample.

\subsection{Elutriation}

Elutriates were prepared according to the method reported in Volpi Ghirardini et al. (2002, 2003). Briefly, the elutriation steps were the following: addition of artificial seawater (Ocean Fish, Prodac International, Cittadella, PD, Italy) to sediment samples at a sample dilution of $1: 4 \mathrm{w}^{\prime} / \mathrm{v}\left(\mathrm{w}^{\prime}=\right.$ sediment dry-weight; $v=$ dilution water volume); stirring of the sediment-water mixture for $24 \mathrm{~h}$ at $230 \mathrm{rpm}$ at $4{ }^{\circ} \mathrm{C}$ using a Jar test (mod. ISCO, Vittadini, Milan, Italy); settling of the mixture for $60 \mathrm{~min}$ at $4{ }^{\circ} \mathrm{C}$; centrifuging 
of the supernatant at $7700 \times g$ at $4{ }^{\circ} \mathrm{C}$ for $15 \mathrm{~min}$ using a refrigerated ultracentrifuge (mod. L7-35, Beckmann, Milan, Italy); storing the supernatant, without filtering, in 100-ml PE containers, and then freezing it at $-18{ }^{\circ} \mathrm{C}$ for later toxicological analyses. Only $100 \mathrm{ml}$ of each elutriate sample were filtered through Whatman GF/F $0.7-\mu \mathrm{m}$ filters, for total ammonia and sulphide analyses.

\subsection{Chemical analyses of elutriates}

Concentrations of sulphides and total ammonia in elutriates were measured with a spectrophotometer (mod. DR/2010, HACH, Loveland, CO, USA) using the methylene blue method (USEPA SM $4500-S 2$ D) for sulphides and the salicylate method (Reardon et al., 1966) for total ammonia. These analyses were performed to evaluate the possible influence of these chemical compounds on elutriate toxicity. The unionized ammonia concentrations were also calculated using the Hampson model (1977) based on Whitfield's equations (1974), based on differing values of $\mathrm{pH}$, temperature and salinity. Elutriate $\mathrm{pH}$ was measured using a $\mathrm{pH}$-meter (perpHecT LogR meter, model 330, Orion, Beverly, MA, USA).

\subsection{Sperm cell and embryo toxicity bioassays}

Adults of P. lividus, collected from an unpolluted site in the northern Adriatic (Italy), close to the barrier island of Pellestrina $\left(45^{\circ} 19^{\prime} 15^{\prime \prime} \mathrm{N}, 12^{\circ}\right.$ $19^{\prime} 26^{\prime \prime} \mathrm{E}$ ), were stored according to the procedures reported in Volpi Ghirardini and Arizzi Novelli (2001), at mean temperature, salinity and $\mathrm{pH}$ of $18.00 \pm 1.35{ }^{\circ} \mathrm{C}, 34.85 \pm 0.49 \%$ and $7.80 \pm 0.19$, respectively (October 2001-April 2002). The fertilization (sperm cell toxicity) test was performed using the procedure developed in our laboratory and reported in detail in the reference cited above. Sea urchins were induced to spawn by injecting 1 $\mathrm{ml}$ of $0.5-1 \mathrm{M} \mathrm{KCl}$ solution. Pools of male and female gametes (minimum three males and three females) were prepared. A volume of $0.1 \mathrm{ml}$ of adjusted suspension of $4 \times 10^{7}$ sperm (thermostated at $18{ }^{\circ} \mathrm{C}$ ) was exposed to $10-\mathrm{ml}$ aliquots of test solution and incubated in a thermostatic bath at 18 ${ }^{\circ} \mathrm{C}$ for $60 \mathrm{~min}$. After exposure, $1 \mathrm{ml}$ of standardized egg suspension (thermostated at $18{ }^{\circ} \mathrm{C}$ ) was added to the sperm suspension and a period of $20 \mathrm{~min}$ was allowed to pass. Samples were preserved in 1 $\mathrm{ml}$ of concentrated buffered formalin, and the percentage of fertilization in each treatment was determined by counting 200 eggs.

The embryo toxicity test was performed using the procedure reported in detail in Arizzi Novelli et al. (2002a). The test consists of the same steps as before, up to sperm and egg density determination, after which the gametes were put together at sperm/egg ratio of 10:1. A period of $20 \mathrm{~min}$ was allowed for fertilization. The test was performed by adding $1 \mathrm{ml}$ of fertilized egg suspension to $10-\mathrm{ml}$ aliquots of test solution, and the aliquots were then incubated in a dark room at $18{ }^{\circ} \mathrm{C}$ for $72 \mathrm{~h}$. At the end of the experiment, samples were preserved in $1 \mathrm{ml}$ of concentrated buffered formalin, and the percentage of plutei with normal development in each treatment was determined by observing 100 larvae.

Male gametes and zygotes were exposed for 60 min and $72 \mathrm{~h}$, respectively, to differing elutriate dilutions $(25 \%, 50 \%, 75 \%, 100 \%)$, using sterile polystyrene six-well microplates with lids (Iwaki Brand, Asahi Techno Glass, Tokyo, Japan) as test chambers. Three experimental replicates were used for each dilution and for control tests, and both toxicity tests were executed at the same time in order to use the same pool of gametes. At the same time, tests were carried out on positive controls (with copper as reference toxicant).

The acceptability of test results was fixed at both a fertilization rate and a percentage of normal plutei of

Table 1

Geographical co-ordinates of the stations and results of grain size and organic matter analyses, and water content for the two core sediment samples (5 and $20 \mathrm{~cm}$ deep)

\begin{tabular}{|c|c|c|c|c|c|c|c|}
\hline \multirow[t]{2}{*}{ Samples } & \multicolumn{2}{|c|}{ Station co-ordinates } & \multicolumn{3}{|c|}{ Grain size $(\%)$} & \multirow{2}{*}{$\begin{array}{l}\mathrm{OM} \\
(\%)\end{array}$} & \multirow{2}{*}{$\begin{array}{l}\text { Water } \\
\text { content } \\
(\%)\end{array}$} \\
\hline & Latitude & Longitude & Sand & Silt & Clay & & \\
\hline SE-5 & $45^{\circ} 27^{\prime} 25^{\prime \prime}$ & $12^{\circ} 25^{\prime} 31^{\prime \prime}$ & 75 & 23 & 2 & 1.4 & 24 \\
\hline SE-20 & & & 76 & 22 & 2 & 0.9 & 20 \\
\hline CEL-5 & $45^{\circ} 26^{\prime} 25^{\prime \prime}$ & $12^{\circ} 21^{\prime} 13^{\prime \prime}$ & 65 & 33 & 2 & 1 & 26 \\
\hline CEL-20 & & & 51 & 45 & 4 & 2.5 & 23 \\
\hline DE-5 & $45^{\circ} 32^{\prime} 16^{\prime \prime}$ & $12^{\circ} 23^{\prime} 14^{\prime \prime}$ & 2 & 56 & 42 & 3.7 & 60 \\
\hline DE-20 & & & 4 & 52 & 44 & 6.5 & 58 \\
\hline TR-5 & $45^{\circ} 26^{\prime} 16^{\prime \prime}$ & $12^{\circ} 15^{\prime} 60^{\prime \prime}$ & 84 & 14 & 2 & 1 & 22 \\
\hline TR-20 & & & 57 & 33 & 10 & 4.1 & 32 \\
\hline
\end{tabular}


$\geq 70 \%$ in all control tests using artificial sea water, and only if the $\mathrm{EC}_{50}$ using the reference toxicant (copper) fell within previously defined acceptability ranges for both tests (Volpi Ghirardini and Arizzi Novelli, 2001; Arizzi Novelli et al., 2002a).

Data are expressed as $\mathrm{EC}_{50}$ values. The percentage of effect was considered to discriminate fewer toxic samples (Volpi Ghirardini et al., 2003). Responses to each treatment (\% of fertilized eggs, $\%$ of normal plutei) were corrected for effects in control tests by applying Abbott's formula. The $\mathrm{EC}_{50}$ values with $95 \%$ confidence limits were calculated using the trimmed Spearman-Karber statistical method (see details in Volpi Ghirardini and Arizzi Novelli, 2001).

\section{Results}

\subsection{Sediment characterization}

Results of grain size and organic matter analyses, and water content for the two core sediment samples (5 and $20 \mathrm{~cm}$ deep) are listed in Table 1, together with
Table 2

Elutriates $\mathrm{pH}$, total sulphides, total ammonia and unionised ammonia concentrations

\begin{tabular}{lcllc}
\hline Sample & $\mathrm{pH}$ & $\begin{array}{l}\text { Total sulphides } \\
(\mathrm{mg} / \mathrm{l})\end{array}$ & $\begin{array}{l}\text { Total ammonia } \\
(\mathrm{mg} / \mathrm{l})\end{array}$ & $\begin{array}{l}\text { Unionised } \\
\text { ammonia }(\mu \mathrm{g} / \mathrm{l})\end{array}$ \\
\hline SE-5 & 8.1 & 0.005 & 2.07 & 66 \\
SE-20 & 8.2 & 0.015 & 1.52 & 61 \\
CEL-5 & 8.3 & 0.012 & 1.67 & 83 \\
CEL-20 & 8.0 & 0.004 & 1.40 & 36 \\
DE-5 & 8.2 & 0.007 & 4.40 & 175 \\
DE-20 & 8.0 & 0.048 & 4.97 & 127 \\
TR-5 & 8.1 & 0.014 & 1.63 & 52 \\
TR-20 & 8.2 & n.d. $^{\text {a }}$ & 4.50 & 179 \\
\hline
\end{tabular}

${ }^{\text {a }}$ Not detectable. Under instrumental detection limits.

the geographical co-ordinates of sites. The table highlights different sedimentological environments for the four sites. Samples from site SE show very similar percentages of sand, silt and clay. Sample CEL-5 shows a larger amount of sandy fraction (65\%) compared with sample CEL-20 (51\%), taking into account that CEL-20 is a homogenized sample, containing also the 5 -cm surficial sediment, and that the deeper layers of the cores should have lower sandy fractions (some calculations indicate that the true

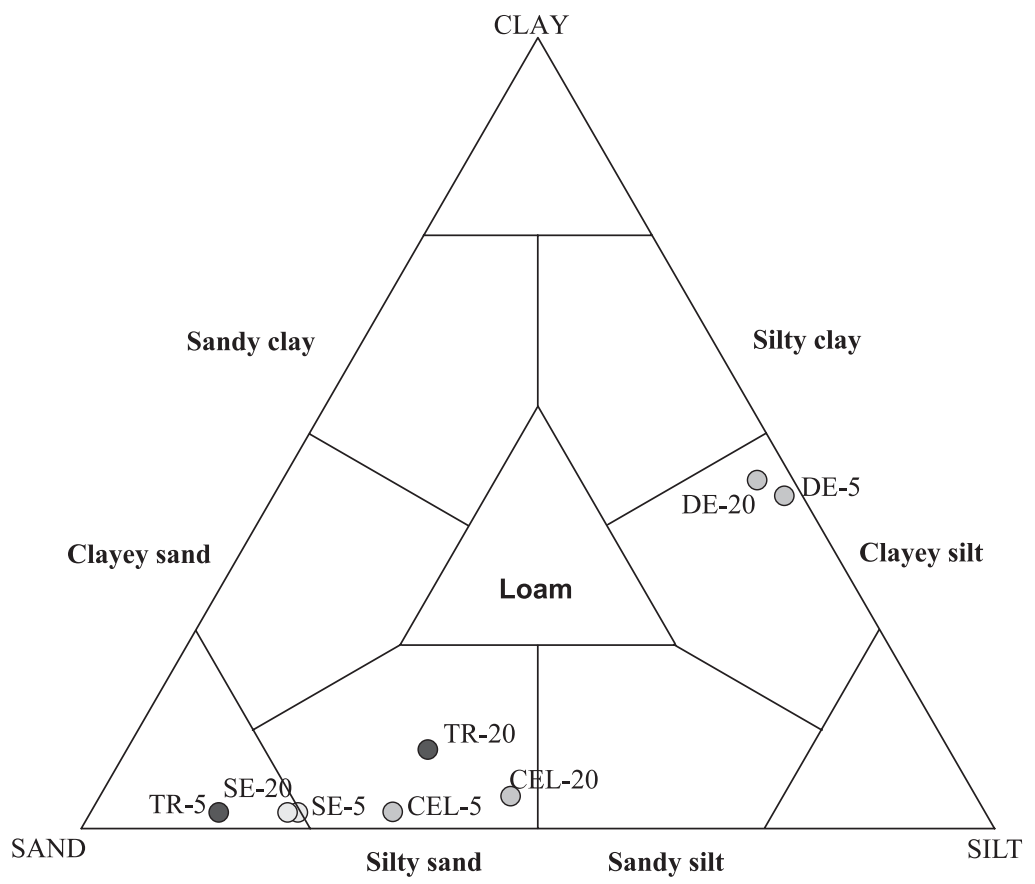

Fig. 2. Classification of sediments according to Shepard. Samples of the core-top $5 \mathrm{~cm}$ and core-top $20 \mathrm{~cm}$ are reported separately. 
sandy value should be $46 \%$ ). The same case is demonstrated in samples from site TR, where TR-5 is sandier (84\%) than TR-20 (57\%); calculations show that the sandy value should be $48 \%$. Samples from site DE show a completely different particle size distribu- tion with respect to the other three sites, confirming the difference in sedimentological environment, where specific physico-chemical processes take place.

According to the Shepard diagram (Shepard, 1954), the sediments were classified in three different

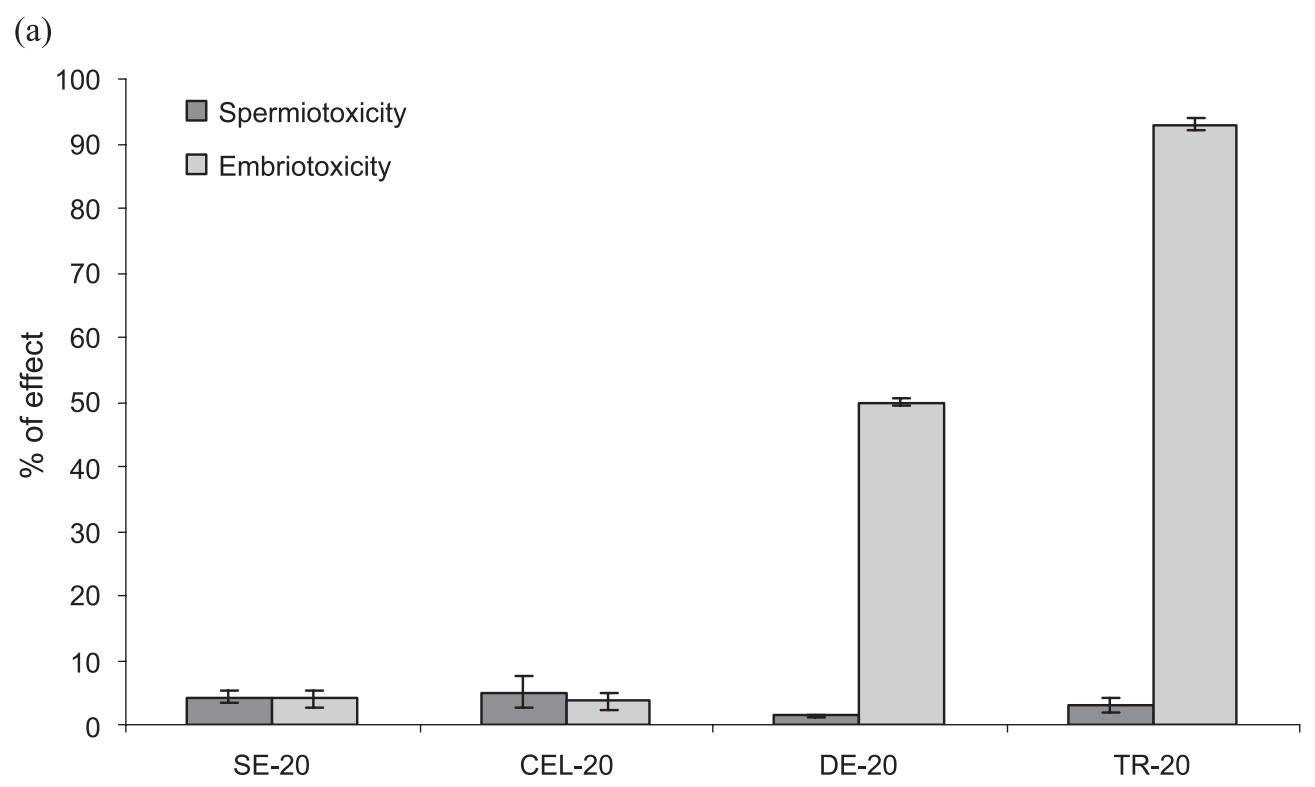

(b)

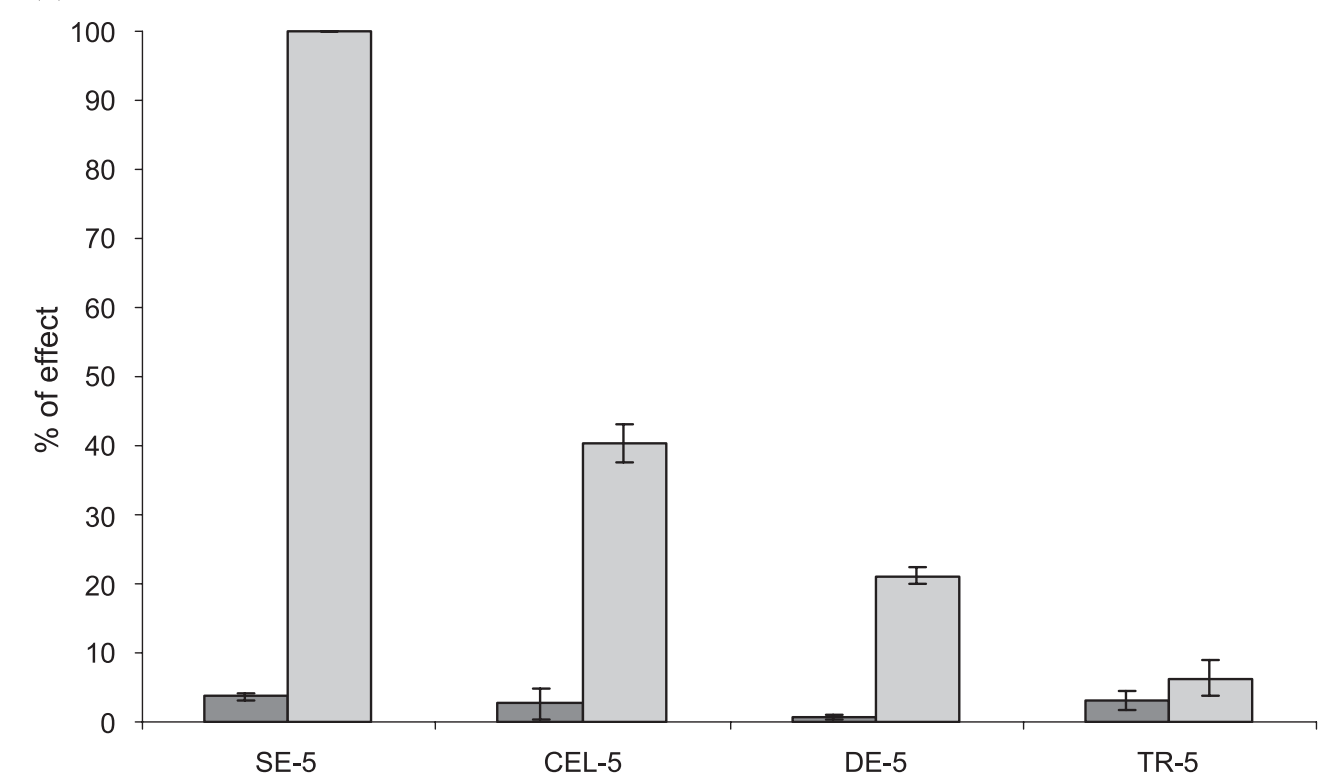

Fig. 3. Results of spermiotoxicity and embryotoxicity tests with $P$. lividus on the elutriates obtained from the core-top $20 \mathrm{~cm}$ (a) and core-top 5 $\mathrm{cm}$ (b) sediments. 
types (Fig. 2). Sediments from site DE were classified as clayey silt, with a percentage of sand lower than 5\%; samples CEL-5, CEL-20 and TR-20 were classified as silty sand, sand ranging from $51 \%$ (CEL-20) to 65\% (CEL-5). Samples TR-5, SE-5 and SE-20 were sandy sediments. All sediment core samples, except for DE-5 and DE-20, had clay content lower than $10 \%$.

As regards organic matter, sample DE-20 exhibited the highest volatile organic matter content $(6.5 \%)$, followed by TR-20 (4.1\%), DE-5 (3.7\%) and CEL-20 $(2.5 \%)$. The other four samples had contents of $1,4 \%$ (SE-5), 1\% (CEL-5 and TR-5) and 0.9\% (SE-20) (Table 1).

As regards water content, percentages in sediments from site DE were from two to three times higher than in the other samples; DE-5 and DE-20, indeed, had water contents of $60 \%$ and $58 \%$, respectively, whereas the other six samples had only $24 \%$ and $20 \%$ (SE-5 and SE-20), 26\% and 23\% (CEL-5 and CEL 20), 22\% and $32 \%$ (TR-5 and TR-20) (Table 1).

\subsection{Chemical analyses of elutriates}

Results of chemical analyses on elutriates are listed in Table 2. All samples had pH from 8.0 (DE-20) to 8.3 (CEL-5). Very low sulphide concentrations were found in all samples $(0.005-0.048 \mathrm{mg} / \mathrm{l})$. Most samples showed total ammonia concentrations ranging from $1.40 \mathrm{mg} / \mathrm{l}$ (CEL-20) to $2.07 \mathrm{mg} / \mathrm{l}$ (SE-5), whereas samples DE-20, TR-20 and DE-5 had values higher than $4 \mathrm{mg} / \mathrm{l}$.

\subsection{Sperm cell and embryo toxicity bioassays}

In all tests performed during the experimental period, controls showed $87 \pm 5 \%$ of fertilized eggs (C.V. $=6.2 \%, n=58)$ and $80 \pm 5 \%$ of normally developed plutei (C.V. $=5.9 \%, n=52)$. Experiments using copper as reference toxicant confirmed the good reproducibility of both assays. The sperm cell test had a mean $\mathrm{EC}_{50} \pm$ standard deviation (S.D.) of $57 \pm 5 \mu \mathrm{g} / \mathrm{l}(\mathrm{C} . \mathrm{V} .=9.5 \%, n=7)$. These data are very similar to previous results $\left(\mathrm{EC}_{50}\right.$ of $56 \pm 8 \mu \mathrm{g} / \mathrm{l}$, C.V. $=15 \%, n=37)$ and well within the $\mathrm{EC}_{50}$ acceptability range (39-71 $\mu \mathrm{g} / \mathrm{l})$ (Volpi Ghirardini and Arizzi Novelli, 2001). The embryo development assay also had good repeatability, with a mean $\mathrm{EC}_{50} \pm$ S.D. of $64 \pm 4 \mu \mathrm{g} / \mathrm{l}(\mathrm{C} . \mathrm{V} .=7 \%, n=6)$. These data too are similar to those found previously $\left(\mathrm{EC}_{50}\right.$ of $65 \pm 7 \mu \mathrm{g} /$ 1, C.V. $=12 \%, n=20)$ and within the acceptability limits $(51-87 \mu \mathrm{g} / \mathrm{l})$ (Arizzi Novelli et al., 2002a).

The results of both tests for elutriates are shown in Fig. 3 and are expressed as percentage of effect for undiluted elutriates. The sperm cell test data revealed extremely low toxicity of all elutriate samples (5 and $20 \mathrm{~cm}$ sediments); indeed, the most spermiotoxic sample was CEL-20, with only $5 \%$ of unfertilized eggs in treatment with undiluted elutriate. Instead, the embryo toxicity assay was able to distinguish the various toxicity responses. It was possible to calculate the $\mathrm{EC}_{50}$ only for the most toxic samples SE-5 and TR-20, which had a percentage of effect $>50 \%$; SE-5 (elutriate extracted from the chosen reference site) showed a mean $\mathrm{EC}_{50} \pm$ S.D. of $39.7 \pm 1.8 \%$ and TR20 a mean $\mathrm{EC}_{50} \pm$ S.D. of $72.8 \pm 0.9 \%$. As Fig. 3 clearly shows, samples CEL-5, DE-5 and DE-20 had abnormal pluteus percentages of $40.3 \%, 21.1 \%$ and $50.0 \%$, respectively, whereas SE-20, CEL-20 and TR5 had extremely low embryo toxicity. Different trends at the two investigated depths were evidenced, with an unexpected "hot spot" of toxicity in sample SE-5.

\section{Discussion}

\subsection{Sediment characterization}

Results of particle size distribution, volatile organic matter and water contents confirm that sediments from site DE were significantly different from sites located in the open Lagoon, highlighted by the highest clay values and water contents (Table 1). Sediment samples from sites DE and SE did not show any grain size differences between the top $5 \mathrm{~cm}$ and top $20 \mathrm{~cm}$. Instead, samples from sites CEL and TR showed a coarser sediment composition in surficial sediment cores $(5 \mathrm{~cm})$, indicating sedimentological processes related to both natural dynamic and possibly induced anthropogenic processes.

Comparisons of the present grain size data for 20 $\mathrm{cm}$ sediment cores, with data from previous works can be made for sites SE, DE and TR. In sites SE and DE, the present data were in agreement with previous studies. The Venice Water Authority (1999) found $78 \%$ of sand in site SE (sediment cores of $15 \mathrm{~cm}$ 
depth, collected in May 1997). Volpi Ghirardini et al. (2002) reported $64 \%$ of silt in site DE (sampling methods were the same as in the present work; samples collected in August 1998). Both results are comparable with our data. In site TR, the present data do not completely fit those of previous studies. The Venice Water Authority, in the above quoted study (1999) on sediment contamination, evidenced finer sediments with a very low percentage of sand (3\%) (sediment cores of $15 \mathrm{~cm}$ depth, collected in October 1997). In October 2000 and April 2001, Volpi Ghirardini et al. (unpublished data) found percentages of $17 \%$ and $71 \%$ of sand, respectively (the sampling method was the same as that of the present work). It appears that only data from April 2001 sampling are in agreement with the present work (Fig. 2). The reason for this substantial difference in results, particularly between our data and the October 2000 sampling data, is not completely clear. It may perhaps be explained by the fact that the island of Tresse is mainly composed of rubble and that this area is also disturbed by several anthropogenic activities.

As regards organic matter, results highlighted that low concentrations were associated with sandy sediments and high concentrations with muds, in agreement with Mayer (1994a,b). Moreover, the highest percentage, found in site DE samples, come from decay of plant debris, since several vegetal fragments deriving from riverine vegetation were found during sample homogenization. The difference in organic matter between the top $5 \mathrm{~cm}$ and top $20 \mathrm{~cm}$ may be explained by the high variability in organic matter content evidenced in the surficial sediments (particularly in the upper $30 \mathrm{~cm}$ ) of wetlands (Mann and Wetzel, 2000).

Water content differences among the four sites were closely related with the different grain size composition of sediments, particularly clay. The clay particles in site DE offer higher adsorption surficials than sandy particles and, consequently, retain more water. Samples from sites SE, CEL and TR had low water contents (about 20-30\%), probably due to the low clay content. Also for water contents, comparisons with previous data were possible for sites SE, $\mathrm{DE}$ and $\mathrm{TR}$, and no evident changes were found (21\%, 60\% and 33-43\%, respectively) (Volpi Ghirardini et al., 2003).

\subsection{Chemical analyses on elutriates}

In order to verify if ammonia and sulphides could seriously influence toxicity by acting as confounding factors, concentrations of these compounds in elutriates and sensitivity data were compared. The sulphide concentrations found in elutriates (Table 2) do not represent a possible confounding factor in sea urchin bioassays: indeed, the $\mathrm{EC}_{50}$ and the NOEC values for P. lividus are respectively 1.20 and $0.11 \mathrm{mg} / 1$ for the sperm cell test, and 0.43 and $0.10 \mathrm{mg} / 1$ for the embryo toxicity test (Losso et al., 2004). The very low value found in elutriates was probably due to volatilization during centrifugation of the supernatant, as Carr (1998) reported that centrifugation may cause great losses of sulphide by off-gassing.

For ammonia (Table 2), only in the case of the samples DE-20, TR-20 and DE-5 could ammonia greatly contribute to toxicity (embryo toxicity), exceeding the $\mathrm{EC}_{50}$ value found for P. lividus $(4.2 \mathrm{mg} /$ 1 as total ammonia, $108 \mu \mathrm{g} / \mathrm{l}$ as unionized ammonia, at pH 8.0) (Arizzi Novelli et al., 2003). In order to verify if recorded environmental concentrations were due to natural conditions, a correlation between sediment volatile organic matter and elutriate total ammonia concentrations was sought, and a positive correlation $\left(r^{2}=0.811\right)$ was found, probably signifying that most of the ammonia present in our elutriate samples derived from decay of organic matter. For samples TR-5, SE-5, SE-20, CEL-5, CEL-20, elutriate ammonia concentrations (both total and unionised) were similar and lower than the above-cited $\mathrm{EC}_{50}$ value although the embryo toxicity results were very different. No correlation was found between total ammonia concentration in undiluted elutriate samples and embryo toxicity. Indeed, sample DE-5 had high ammonia and a negligible or low toxic effect. In conclusion, this study of confounding factors allows us to confirm that the "hot spot" of SE-5 showed high toxicity-not attributable to ammonia but produced by an unidentified mixture of pollutants.

\subsection{Sperm cell and embryo toxicity bioassays}

The differing results shown by sperm cell and embryo toxicity tests were congruent with test sensitivities, previously investigated using both pure substances and elutriates (Volpi Ghirardini et al., 2003). 
The sensitivity of the sperm cell test is in fact similar to that of an acute test, only highlighting great toxicity in elutriates, whereas the embryo toxicity test may be considered short-term chronic, due to its higher sensitivity. Although the sperm cell test did not discriminate the toxicity of the elutriate samples tested in this study, previous works demonstrate that it can reveal elutriate toxicity in both surficial sediments (top 20 $\mathrm{cm})$ in very polluted sites of the industrial area (Brentelle industrial canal) and bottom sediments (several meters depth) of the port of Venice (Arizzi Novelli et al., 2002b). Therefore, the sperm cell toxicity test results obtained here allow us to consider as negligible the acute toxicity of elutriates from sediments of the study sites.

The embryo toxicity test showed a resolution power higher than that of the sperm cell toxicity test, in accordance with its higher sensitivity, discriminating between the differing toxic responses of elutriate samples and clearly evidencing the presence of possible chronic toxicity. Toxicity data obtained with sea urchin embryo toxicity test are very similar to embryotoxicity data evidenced by test using the oyster Crassostrea gigas (Thunberg, 1793), applied to some of the same elutriates according to the protocol by His et al. (1997): the percentage of effect for CEL-20, CEL-5, SE-20, SE-5 are respectively $2 \%, 34 \%, 39 \%$ and $100 \%$ (Volpi Ghirardini et al., unpublished data). We can exclude the influence of ammonia in toxicity data obtained with oysters for S. Erasmo and Celestia sites because both total and unionised ammonia of elutriates are below the threshold values $(4.7 \mathrm{mg} / \mathrm{l}$ for total ammonia and $0.13 \mathrm{mg} / \mathrm{l}$ for unionised ammonia) reported by ASTM (1998) for standard methods with $C$. gigas.

The embryotoxicity gradient with sea urchin for elutriates extracted from the sediment cores of $20 \mathrm{~cm}$ (TR-20 $>$ DE-20 $>$ CEL-20 $=$ SE-20) (Fig. 3a) generally fitted the expected contamination gradient shown by previous chemical data. Existing data did show high concentrations of heavy metals and organic micropollutants in TR sediments, whereas SE was the least contaminated site. Sediments from sites CEL and DE were characterized by intermediate heavy metals and organic pollutant contamination (see Section 2.1). Although chemical analyses showed different contamination levels, CEL-20 toxicity was very similar to that found for sample SE-20 (mean abnormal pluteus percentages of $3.7 \%$ and $4.0 \%$, respectively). The gradient obtained using the embryo toxicity test also fitted results obtained by applying in parallel another toxicity bioassay (Microtox ${ }^{\circledR}$ solid-phase) to the same sample cores of $20 \mathrm{~cm}$ (Volpi Ghirardini et al., unpublished data), according to the modified protocol reported in previous papers (Volpi Ghirardini et al., 1998, 1999). The Microtox ${ }^{\circledR}$ solid-phase test revealed the following gradient in toxicity (expressed as Toxicity Units 50): TR-20 (T.U. ${ }_{50}=$ $11040)>$ DE $-20 \quad($ T.U. $50=7288)>$ CEL -20 $($ T.U.50 $=5884)>$ SE-20 (T.U. $.50=1667)$, bacteria being better able to discriminate between CEL-20 and SE-20. Moreover, the sediment toxicity value in the potential reference site (SE-20) was higher with respect to other clean sites previously investigated in the Lagoon of Venice. The value for TR-20 was the highest found in the open Lagoon (Volpi Ghirardini et al., 1998, 1999).

Elutriate toxicity of the top $5 \mathrm{~cm}$ sediments revealed a marked gradient (SE-5 $>$ CEL-5 $>$ DE5>TR-5) (Fig. 3b), totally inverted in comparison with that for the $20 \mathrm{~cm}$ sediments. These results may be the direct consequence of redistribution of polluted particulate matter in the Lagoon of Venice, according to the complex hydrodynamics of this ecosystem (Melaku Canu et al., 2001).

\section{Conclusions}

This work aimed at providing evidences of sediment toxicity using acute and short-term chronic tests with sea urchin on elutriates, identifying possible confounding factors of toxicity (such as ammonia and sulphides) and taking into account the physicochemical characteristics of sediments (particle size, organic matter and water content). Integrated physicochemical and toxicity results on sediments at different depths demonstrated the presence of disturbed sediments in the central basin of the Lagoon of Venice.

The toxicity gradient (embryo toxicity bioassay) for $20-\mathrm{cm}$ sediment cores generally fitted data concerning chemical contamination and other toxicity bioassays (Microtox ${ }^{\circledR}$ solid-phase), whereas a completely unexpected and inverted trend of toxicity was found in the core-top 5-cm surficial sediment, with respect to that of $20 \mathrm{~cm}$. At the same time, particle 
size data showed coarser sediment composition in some surficial sediments, with great differences in composition from top $5 \mathrm{~cm}$ and top $20 \mathrm{~cm}$. Moreover, an unexpected "hot spot" of toxicity was found in the more surficial layer of the site chosen as a possible reference, also confirmed by embryo toxicity test with the oyster $C$. gigas.

These results suggest that, in the central basin of the Lagoon of Venice, resuspension phenomena remove pollutants from polluted area redepositing them according to the tidal currents. In this context, effects on resident water column organisms cannot be excluded and should be closely investigated.

Environmental matrices used for toxicity bioassays thus turn out to be suitable for investigating sediment quality. In particular, elutriate toxicity did not seem to be greatly affected by confounding factors such as sulphide and ammonia contents in the study sites.

Lastly, as results showed that sedimentological processes, at least in surficial sediments, may be influenced by anthropogenic activities; improved knowledge of sediment dynamic and erosion processes in the Lagoon of Venice will require further studies.

\section{Acknowledgements}

This work was partly funded by the Consorzio Ricerche Laguna (Co.Ri.La.) of Venice (Italy). The authors are very grateful to Emanuele Argese for his kind collaboration and Mario Pistolato for sedigraphic analyses. Gabriel Walton revised the English text.

\section{References}

Arizzi Novelli, A., Volpi Ghirardini, A., Giuliani, S., Falugi, C., Pagano, G., Iaccarino, M., 2001. Valutazione della tossicita' di acque e sedimenti costieri su gameti e embrioni di specie autoctone di ricci di mare utilizzando metodiche differenziate. Giornata di studio "Indagini ecotossicologiche negli ambienti marini costieri in riferimento al D.L. 152/99", Roma 6 marzo 2001. Biologia Marina Mediterranea 2, 41-59.

Arizzi Novelli, A., Argese, E., Tagliapietra, D., Bettiol, C., Volpi Ghirardini, A., 2002a. Toxicity of tributyltin and triphenyltin to early life stages of Paracentrotus lividus (Echinodermata: Echinoidea). Environmental Toxicology and Chemistry 21, $859-864$.

Arizzi Novelli, A., Volpi Ghirardini, A., Losso, C., Marchetto, D., Picone, M., Ghetti, P.F., 2002b. Valutazione della tossicità dei sedimenti di ambienti di transizione: applicazione dei saggi con l'echinoide Paracentrotus lividus alla laguna di Venezia. XII Congresso Nazionale della Società Italiana di Ecologia. Urbino, 16-18 settembre 2002.

Arizzi Novelli, A., Picone, M., Losso, C., Volpi Ghirardini, A., 2003. Toxicity of ammonia at differing $\mathrm{pH}$ in embryo toxicity bioassays using the sea urchin Paracentrotus lividus (Lmk). Ecotoxicology and Environmental Safety 85 (4-6), $183-191$.

ASTM, 1990. Standard guide for collection, storage, characterization, and manipulation of sediments for toxicological testing. American Society for Testing and Materials, E1390-E1391.

ASTM, 1995. Standard guide for conducting static acute toxicity tests with echinoid embryos. American Society for Testing and Materials, E1563-E1595.

ASTM, 1998. Standard guide for conducting static acute toxicity tests with four species of saltwater bivalve molluscs. American Society for Testing and Materials, E724-E798.

Carr, R.S., 1998. Marine and estuarine porewater toxicity testing. In: Wells, P.G., Blaise, Lee, K. (Eds.), Microscale Testing in Acquatic Toxicology: Advances, Techniques, and Practise. CRC Press, Boca Raton, FL, pp. 523-538.

Critto, A., Marcomini, A., 2001. Rischio ecologico e inquinamento chimico lagunare, Cafoscarina Ed ISBN 88-88613-19-6, pp. 162.

Da Ros, L., Marin, M.G., Fossato, V.U., Campesan, G., 1997. Sedimenti lagunari: prove di tossicità su embrioni di riccio di mare, Paracentrotus lividus. Biologia Marina Mediterranea 4, 632-636.

Environment Canada, 1992. Biological tests methods: fertilization assay using echinoids (sea urchin and sand dollar). Environmental Protection Series (1/RM/27), 133 p.

Facca, C., Sfriso, A., Socal, G., 2002. Changes in abundance and composition of phytoplankton and microphytobenthos due to increased sediment fluxes in the Venice Lagoon, Italy. Estuarine, Coastal and Shelf Science 54, 773-792.

Hampson, B.L., 1977. Relationship between total ammonia and free ammonia in terrestrial and ocean waters. Journal du ConseilInternational pour l'Exploration de la Mer 37, 117-122.

His, E., Seaman, R.N.L., Beiras, R., 1997. A simplified bivalve larval bioassay method for seawater quality assessment. Water Research 31, 351-355.

ICES, 1997. International Council for the Exploitation of the Sea, Report of the ICES Advisory Committee on the Marine Environment.

Lapota, D., Duckworth D., Word, J., 2000. Confouding factors in sediment toxicology. Issue papers: 1-19. SPAWAR Systems Center San Diego. http://web.ead.anl.gov/ecorisk/issue/pdf/ confound.pdf.

Losso, C., Arizzi Novelli, A., Picone, M., A., Volpi Ghirardini, A., Ghetti, P.F., Budello, D., Ugo, P., 2004. Sulphide as confounding factor for toxicity bioassays with the sea urchin Paracentrotus lividus: comparison with chemical analysis data. Environmental Toxicology and Chemistry 23 (2), 396-401.

Mann, C.M., Wetzel, R.G., 2000. Hydrology of an impounded lotic wetland-wetland sediment characteristics. Wetlands 20 (1), $23-32$. 
Mayer, L.M., 1994a. Surface area control of orgabnic carbon accumulation in continental shelf sediments. Geochimica et Cosmochimica Acta 58, 1271-1284.

Mayer, L.M., 1994b. Relationship between mineral surfaces and organic carbon concentrations in soils and sediments. Chemical Geology 114, 347-363.

McFadzen, I.R.B., 2000. Determination of water quality in the Venice lagoon utilizing the early life stages of a fish (Sparus aurata) and an echinoderm (Paracentrotus lividus). In: Lasserre, P., Marzollo, A. (Eds.), The Venice Lagoon Ecosystem: Inputs and Interactions Between Land and Sea, MAB vol. 25, UNESCO, Paris, 339-355.

Melaku Canu, D., Umgiesser, G., Solidoro, C., 2001. Short-term simulations under winter conditions in the lagoon of Venice: a contribution to the environmental impact assessment of temporary closure of the inlets. Ecological Modelling 138, 215-230.

Nendza, M., 2002. Inventory of marine biotest methods for the evaluation of dredged material and sediments. Chemosphere $48,865-883$.

Orel, G., Boatto, V., Sfriso, A., Pellizzato, M., 2000. Piano per la gestione delle risorse alieutiche delle lagune della Provincia di Venezia. Provincia di Venezia, Venice, Italy, pp. 1-102.

Pranovi, F., Giovanardi, O., 1994. The impact of hydraulic dredging for short-neched clams, Tapes spp., on an infaunal community in the Venice Lagoon. Scientia Marina 58 (4), 345-353.

Ravera, O., 2000. The lagoon of Venice: the result of both natural and human influence. Journal of Limnology 59 (1), 19-30.

Reardon, J., Foreman, J.A., Searcy, R.L., 1966. New reactants for the colorimetric determination of ammonia. Clinica Chimica Acta 14 (3), 203-205.

Rosselli, R., Silvestri, S., Zandonella, A., 2002. Funzioni e strumenti del Servizio Informativo. L'applicazione del telerilevamento per l'analisi e la gestione del territorio lagunare. Edited by Ministero delle Infrastrutture e dei Trasporti, Magistrato alle Acque di Venezia (Eds.), Quaderni Trimestrali Consorzio Venezia Nuova, vol. $\mathrm{X}$, Ministero della Infrastrutture e dei Trasporti, Magistrato alle Acque di Venezia, pp. 1-80.

Sfriso, A., Marcomini, A., 1996. Decline of Ulva growth in the Lagoon of Venice. Bioresource Technology 54, 299-307.

Sfriso, A., Facca, C., Ceolo, S., Silvestri, S., Ghetti, P.F., 2003. Role of macroalgal biomass and clam fishing on spatial and temporal changes in $\mathrm{N}$ and $\mathrm{P}$ sedimentary pools in the central part of the Venice lagoon. Oceanologica Acta 26, 3-13.

Shepard, F.P., 1954. Nomenclature based on sand-silt-clay ratios. Journal of Sedimentary Petrology 24, 151-158.

U.S. EPA, 1994. Short-Term Methods for Estimating the Chronic
Toxicity of Effluents and Receiving Water to Marine and Estuarine Organisms. U.S. Environmental Protection Agency, Cincinnati, OH. 600/4-91/003.

U.S. EPA, 1995. Short-Term Methods for Estimating the Chronic Toxicity of Effluents and Receiving Water to West Coast Marine and Estuarine Organisms. U.S. Environmental Protection Agency, Cincinnati, OH. 600/R-95/136.

U.S. EPA, 2000. Estuarine and Coastal Marine Waters: Bioassessment and Biocriteria Technical Guidance. U.S. Environmental Protection Agency, Office of Water, Washington, DC, p. 20460. EPA-822-B-00-024.

U.S. EPA, U.S. ACE, 1998. Evaluation of Dredged Material Proposed for Discharge in Waters of the US-Testing Manual US Environmental Protection Agency and US Army Corps of Engineers, Washington, DC. EPA/823-B-94/002.

Venice Water Authority, 1999. "Mappatura dell'inquinamento dei fondali lagunari" Project (1998-1999), Ministry of Public Works-Venice Water Authority-Consorzio Venezia Nuova, Final Report.

Volpi Ghirardini, A., Arizzi Novelli, A., 2001. A sperm cell toxicity test procedure for the Mediterranean species Paracentrotus lividus (Echinodermata: Echinoidea). Environmental Technology $22,439-445$.

Volpi Ghirardini, A., Ghetti, P.F., Di Leo, V., Pantani, C., 1998. Microtox solid-phase bioassays in sediment toxicity assessment. Verh.-Int. Ver. Limnol. 26, 2393-2397.

Volpi Ghirardini, A., Birkemeyer, T., Arizzi Novelli, A., Delaney, E., Pavoni, B., Ghetti, P.F., 1999. An integrated approach to sediment quality assessment: the Venetian lagoon as a case study. Aquatic Ecosystem Health and Management 2, 435-447.

Volpi Ghirardini, A., Arizzi Novelli, A., Borsetto, B., Delaney, E., Tagliapietra, D., 2001. Sediment toxicity assessment in the Venetian Lagoon using Paracentrotus lividus (Echinodermata: Echinoidea). Biologia Marina Mediterranea 8 (1), 489-496 (in Italian).

Volpi Ghirardini, A., Arizzi Novelli, A., Tagliapietra, D., 2004. Sediment toxicity assessment in the Lagoon of Venice (Italy) using Paracentrotus lividus (Echinodermata: Echinoidea) fertilization and embryo bioassays. Environmental International (in press).

Volpi Ghirardini, A., Arizzi Novelli, A., Losso, C., Ghetti, P.F., 2003. Sea urchin toxicity bioassays for sediment quality assessment in the Lagoon of Venice (Italy). Chemistry and Ecology 19 $(2-3), 99-111$.

Wang, F., Chapman, P.M., 1999. Biological implications of sulphide in sediment - a review focusing on sediment toxicity. Environmental Toxicology and Chemistry 18 (11), 2526-2532. 